\title{
A arte como refúgio: intertextualidade, espaço e (imagi)nação em "Aqueles dois", de Caio Fernando Abreu
}

\author{
Art as Refuge: Intertextuality, Space, and (Imagi)nation \\ in "Aqueles dois," by Caio Fernando Abreu
}

\author{
El arte como refugio: intertextualidad, espacio y (imagi)nación
} en "Aqueles dois", de Caio Fernando Abreu

Jacob Brown ${ }^{*}$

\section{Resumo}

Este artigo analisa a intertextualidade em "Aqueles dois", do livro Morangos mofados (1982), de Caio Fernando Abreu. Diversos estudos investigam o conto por meio da teoria queer, mas só alguns examinam atentamente suas diversas referências intertextuais à arte, à poesia, à música e ao cinema. As obras de arte e cultura que são referenciadas, aliás, tendem a vir do exterior, contribuindo para visão cosmopolita do conto para um Brasil que ainda estava em plena transição de Ditadura Militar à democracia. Portanto, o artigo argumenta que a intertextualidade em "Aqueles dois" não somente sugere a atração homoerótica entre os protagonistas, Raul e Saul, mas também enriquece o significado simbólico dos espaços públicos e íntimos do conto. Especificamente, as referências ao quadro "Quarto em Arles", de Vincent Van Gogh, reforçam o senso de segurança e tranquilidade que os protagonistas gozam enquanto estão juntos em casa - e fora do olhar público. Além de pintura, as referências à poesia de Walt Whitman, aos boleros hispano-americanos e ao cinema de Hollywood não apenas intensificam a temática homoafetiva do conto, mas também representam um refúgio aonde os protagonistas fogem da repressão da sociedade brasileira, mesmo só através da arte e da imaginação. Deste modo, a intertextualidade é fundamental para a dimensão social da obra de Caio Fernando Abreu. Apesar da abertura da vida cultural do Brasil, depois da promulgação da Lei de Anistia em 1979, "Aqueles dois" atesta a homofobia como legado da ditadura durante o período da transição, e continua sendo uma leitura relevante na atualidade.

Palavras-chave: sexualidade, intertextualidade, espaço, cosmopolitismo, Ditadura Militar.

\section{Abstract}

This article analyzes intertextuality in "Aqueles dois" ["Those Two"], from the collection Morangos mofados ["Spoiled Strawberries"] (1982), by Brazilian author Caio Fernando Abreu. Many studies have approached the short story through a queer theoretical lens, but only a few have deeply engaged with the its various intertextual references to art, poetry, music, and film. Moreover, the artistic, literary, and pop cultural works that are referenced in the short story tend to be from abroad, thereby composing a cosmopolitan vision for a Brazil still in transition from military dictatorship to democracy. This article therefore argues that intertextuality in "Aqueles dois" not only hints toward the homoerotic attraction between the protagonists, Raul and Saul, but also enriches the story's public and intimate spaces with symbolic meaning. Specifically, the allusions to the painting "Bedroom in Arles," by Vincent Van Gogh, reinforce the sense of security

\section{Resumen}

Este artículo analiza la intertextualidad en "Aqueles dois" ["Aquellos dos"], de la colección Morangos mofados (1982), de Caio Fernando Abreu. Muchos estudios se acercan al cuento mediante la teoría queer, pero sólo algunos examinan atentamente sus diversas referencias intertextuales al arte, a la poesía, a la música y al cine. Las obras referenciadas suelen venir asimismo del extranjero, contribuyendo a la visión cosmopolita del cuento para un Brasil en plena transición de la dictadura militar a la democracia. El presente artículo, por lo tanto, argumenta que la intertextualidad en "Aqueles dois" no solamente sugiere la atracción homoerótica entre los protagonistas, Raul y Saul, sino que también enriquece los espacios públicos e íntimos del cuento con significado simbólico. Específicamente, las alusiones al cuadro "Cuarto en Arles", de Vincent Van Gogh, refuerzan el sentido de

\footnotetext{
*Vanderbilt University, Nashville, TN, Estados Unidos. Dorcid.org/0000-0002-8273-1506. E-mail: jacob.c.brown@vanderbilt.edu
} 
and peace that the protagonists enjoy while being together inside of each other's apartments - and outside of the public eye. In addition, the references to the poetry of Walt Whitman, to Hispanic American boleros and to Hollywood cinema not only intensify the story's homoerotic overtones but also represent a refuge in which the protagonists escape the repression of Brazilian society, if only through the transportive power of art and imagination. Intertextuality thus plays a fundamental role within the sociopolitical dimension of Caio Fernando Abreu's work. Despite the gradual opening of political and cultural life after the 1979 Amnesty Act, "Aqueles dois" attests to the dictatorship's legacy of homophobia in Brazil during the period of transition to democracy, and it continues to be relevant reading to this day.

Keywords: sexuality, intertextuality, space, cosmopolitism, military dictatorship. seguridad y tranquilidad que los protagonistas disfrutan mientras están juntos en casa - y fuera de la mirada pública. Además de pintura, las referencias a la poesía de Walt Whitman, a los boleros y a las películas de Hollywood no solamente intensifican la temática homoafectiva del cuento, sino que también representan un refugio adonde los protagonistas se fugan de la represión de la sociedad brasileña, aunque sólo a través del arte y de la imaginación. De este modo, la intertextualidad es fundamental para la dimensión social de la obra de Caio Fernando Abreu. A pesar de la apertura de la vida cultural de Brasil después de la promulgación de la Ley de Amnistía de 1979, "Aqueles dois" atesta a la homofobia como legado de la dictadura durante el periodo de la transición, y sigue siendo una lectura pertinente en la actualidad.

Palabras-clave: sexualidad, intertextualidad, espacio, cosmopolitismo, dictadura militar.

O conto "Aqueles dois: história de aparente mediocridade e repressão", publicado pela primeira vez em 1982, no livro Morangos mofados, reflete a realidade social, cultural e política do Brasil nos últimos anos da Ditadura Militar. ${ }^{1}$ Expressa o desejo de realizar outro Brasil, afetivamente aberto e cosmopolita, latente e possível, enquanto ainda estava preso entre a persistência da ditadura e a volta da democracia. Morangos mofados foi publicado três anos depois da promulgação da Lei da Anistia, em 1979, ato que restabeleceu direitos políticos, dando, assim, um passo em direção à restauração da democracia constitucional no país. Por causa dessa lei, a censura se afrouxou, permitindo que ex-presos políticos e exilados publicassem suas histórias no Brasil. ${ }^{2}$ Após um período em que o próprio autor foi alvo do Departamento de Ordem Política e Social (DOPS), Morangos mofados desfrutou da liberdade para não só tratar de temas homoafetivos, mas também criticar a cultura brasileira sob o regime militar - que continuaria até a eleição indireta de 1985, portanto, até vinte e um anos depois do golpe militar em 1964. ${ }^{3}$ Enquanto outros contos de Morangos mofados (como "Sargento Garcia" e "Terça-feira gorda") enfrentam a temática homoerótica diretamente, "Aqueles dois" (Abreu, 2018b) demonstra a sutileza do autor ao construir a ambiguidade do relacionamento/amizade dos dois protagonistas, Raul e Saul. Em virtude da suspeita de que eles estivessem mantendo um relacionamento romântico, os dois jovens são despedidos da firma onde trabalhavam. O conto recorre, nas entrelinhas, a referências à arte, poesia, música e cinema - notavelmente do exterior - para comunicar-se com um público leitor criativo, culturalmente informado e capaz de ligar os pontos entre texto e intertexto. Além de reforçar a temática homoafetiva do conto, os intertextos de "Aqueles dois" representam refúgios imaginários da vida cotidiana da empresa em que trabalhavam os protagonistas. Eles não se veem representados na cultura nacional massificada dos seus colegas de trabalho, mas sim em outras culturas distantes da ditadura brasileira. Deste modo, as referências intertextuais permitem

\footnotetext{
${ }^{1}$ Este artigo analisa a versão de Morangos mofados que se encontra em Caio Fernando Abreu: contos completos, publicado em 2018. Nesse sentido, é importante destacar que, em nota assinada em 1995, o autor indica que, para "depurar" os morangos, submeteu o texto original a uma "severa revisão de forma"; contudo, "nada em seu conteúdo ou estrutura foi modificado, mas a pontuação foi retrabalhada, novos parágrafos foram abertos ou eliminados etc." (Abreu, 2018a, p. 316).

${ }^{2}$ Ver a análise do segundo período da literatura sobre a ditadura (1979-2000) em Figueiredo (2017, p. 63-86).

${ }^{3}$ A "Cronologia" no apêndice de Abreu (2018a) indica que o autor escondeu-se de dezembro de 1968 a abril de 1969, começo dos notórios anos de chumbo: "Com a decretação do AI-5, refugia-se durante alguns meses na Casa do Sol, sítio da poeta Hilda Hilst, sua amiga, em Campinas (SP), depois de se tornar alvo do DOPS. Durante esse período, escreve a maior parte dos contos de Inventário do irremediável" (Abreu, 2018a, p. 757-758).
} 
que Raul e Saul fujam da "aparente mediocridade e repressão" da nação, alegorizadas pela mediocridade e repressão da empresa.

A intertextualidade também ajuda a construir sentido para os espaços interiores e exteriores do conto. Por um lado, o quadro "Quarto em Arles", de Vincent Van Gogh, representa a segurança que os protagonistas sentem nos espaços interiores de seus dormitórios, longe dos comentários, olhares e julgamentos de seus companheiros. Por outro lado, a epígrafe, um trecho de "So long!", de Walt Whitman, expressa o desejo ainda não realizado de se amar abertamente em público, ou seja, nos espaços exteriores dos cafés, nas salas de trabalho e nos cenários urbanos onde eles se encontram. A arte de Van Gogh e a poesia de Walt Whitman, portanto, servem no conto para ilustrar a separação binária, não só entre o interior e o exterior, mas também entre a segurança e a liberdade. Por meio de atos institucionais (especialmente o AI-5), a ditadura suspendia liberdades individuais com a justificativa de aumentar proteções contra o comunismo, os "transgressores da moral" e outros percebidos inimigos da nação - inclusive os homossexuais. Contudo, mesmo depois da Lei de Anistia, o conto mostra que a ditadura continuava criando um senso não de segurança, mas de terror em cidadãos que não se encaixavam dentro dos padrões heteronormativos de gênero e sexo, representados por Raul e Saul. Desajeitados tanto na cultura da firma quanto na nação, os protagonistas buscam refúgio no mundo das artes, principalmente do exterior. Além das referências a Van Gogh e Walt Whitman no conto, os protagonistas escutam boleros hispânicos, assistem a filmes de Hollywood juntos e, assim, participam de culturas longínquas da suspeita e da paranoia acerca do seu relacionamento ambíguo. Dentro da segurança dos seus próprios apartamentos, os protagonistas olham para fora - através de arte, poesia, música e cinema estrangeiros - para descontruir a cultura do Brasil de tradicionalismo, nacionalismo e "bons costumes", parodiada no conto por "mulheres malamadas e vorazes, os papos de futebol, amigo secreto, lista de presente, bookmaker, bicho, endereço de cartomante, clips no relógio de ponto, vezenquando salgadinhos no fim do expediente, champanha nacional em copo de plástico" (Abreu, 2018b, p. 405). Através das referências intertextuais à arte e à cultura de fora, o conto constrói uma nova cultura culta, cosmopolita e "diferente" no Brasil, mesmo que seja apenas entre "aqueles dois".

Para contribuir aos vários estudos que já abordam a temática homoerótica na obra de Caio Fernando Abreu, este artigo destaca o uso da intertextualidade no conto como testemunho da lenta abertura e, simultaneamente, a persistente repressão cultural durante os últimos anos da ditadura brasileira. Vários críticos já notaram que a temática homoerótica em Morangos mofados costuma ser acompanhada por temas que se estendem desde confusão, estranhamento e euforia até preconceito, repressão e abuso. Apesar da variedade de representação do homoerotismo nos contos, todos refletem as atitudes sociais de homens gays durante o período da transição da Ditadura Militar. As epígrafes guiam a leitura do livro antes mesmo de começar os contos. A primeira epígrafe é de Federico García Lorca (1898-1936), poeta e dramaturgo espanhol que foi capturado pelos nacionalistas durante a Guerra Civil Espanhola e assassinado num campo de Granada por ser escritor, intelectual e homossexual. A citação dele em Morangos mofados, "Dejadme en este campo llorando", que podemos traduzir por "Me deixem neste campo chorando" ressoa com o triste final de Lorca e gesticula às semelhanças entre as ditaduras da Espanha e do Brasil durante o século XX. Para reforçar o paralelo entre ditaduras, a segunda epígrafe é do poema "Monstro de fumaça", de Henrique do Valle, poeta brasileiro que foi exilado com sua família aos 6 anos em 1964 e buscou o sentido da vida num mundo opressivo, até sua morte em 1981, aos 22 anos. O primeiro conto, "Diálogo", engaja-se nessa busca do sentido das palavras em uma conversa tediosa ad infinitum sobre o que quer dizer "companheiro", possivelmente sugerindo a ambiguidade da palavra para significar amigo ou parceiro romântico. Dois dos contos que tratam do homoerotismo mais explicitamente são "Terça-feira gorda" e "Sargento Garcia". No primeiro, dois homens se beijam numa festa de Carnaval e são atacados por uma multidão; no segundo, um garoto é iniciado sexualmente por uma figura de autoridade - nada menos que um sargento e símbolo da Ditadura Militar. 
Ao contrário de "Terça-feira gorda" e "Sargento Garcia", "Aqueles dois" não contém descrições gráficas de beijos apaixonados, suor, pelos e paixão. Quanto a contato físico, Raul e Saul não fazem mais do que se abraçar apertadamente (coisa comum até entre homens hétero na cultura brasileira). A ambiguidade da relação entre os protagonistas é mantida ao longo do conto. Mesmo assim, diversos estudiosos já analisaram o conto através da lente da teoria queer desde a publicação do artigo "Literatura e homoerotismo: a perspectiva queer em 'Morangos mofados', de Caio Fernando Abreu" (Calegari, 2007). ${ }^{4}$ Portanto, já não parece verdade a declaração de Calegari (2007, p. 117) de que, "Estudos acerca das relações entre literatura e sexualidade são pouco difundidos dentro do âmbito acadêmico brasileiro". Ao contrário, parece que os estudos queer são dominantes na crítica literária sobre Caio Fernando Abreu, ponto afirmado por Pereira (2016) em "A construção do (des)sabor d'aqueles dois Morangos mofados". $\mathrm{O}$ artigo argumenta que, apesar da "espécie estranha e confusa e gigantesca e também leve e pura de amor" entre Raul e Saul em "Aqueles dois", "seria limitar a escrita de Caio Fernando Abreu afirmar que este conto trata somente e só de uma questão homoafetiva; do amor entre duas pessoas do mesmo sexo. O conto vai além e ocupa-se, como em seu subtítulo, com uma 'história de aparente mediocridade e repressão'" (Pereira, 2016, p. 87).

Reduzimos o legado do autor, em vez de enriquecê-lo, quando deixamos de analisar sua obra de vários pontos de vista. Por isso, este artigo pretende conectar os aspectos socioculturais do conto com uma técnica literária importante na obra de Caio Fernando Abreu: a intertextualidade. Como se discute nas próximas seções, Gonella (2015) e Pereira (2016) comentaram algumas das referências internas no conto em questão. Tentamos continuar contribuindo para a discussão por nos aprofundarmos mais na análise das várias referências intertextuais do conto, inspirando-nos no marco analítico de Eurídice Figueiredo - ou seja, lendo o conto no contexto histórico dos últimos anos da ditadura brasileira.

\section{Conto e contexto: "Aqueles dois" como arquivo da transição da ditadura brasileira}

Além de apoiar a leitura queer de vários estudos sobre o conto, a intertextualidade poética, artística e audiovisual ilustra a ideia desenvolvida por Eurídice Figueiredo (2017) da literatura como arquivo da ditadura brasileira. Os prévios estudos sobre Caio Fernando Abreu interpretam "Aqueles dois" como uma crítica à sociedade brasileira e sobretudo à homofobia dentro do contexto nacional e histórico do "ponto tenso de passagem da Ditadura Militar ao regime democrático no Brasil" (Ginzburg, 2012, p. 408). No entanto, "Aqueles dois" demostra que essa passagem abriu espaço para uma visão cosmopolita do Brasil, que abrange críticas tanto ao patriarcado quanto ao patriotismo oficializados pelo regime militar durante mais de duas décadas da história do país. Ao mesmo tempo que "Aqueles dois" ilustra a homofobia paranoica herdada das repressões do governo durante o auge da ditadura, também demonstra que a literatura gozava da liberdade para sonhar publicamente com um Brasil "diferente", ainda em plena ditadura, depois da promulgação da Lei de Anistia. Por meio das referências à arte holandesa, à música hispano-americana, à poesia e ao cinema estadunidenses, o cosmopolitismo de "Aqueles dois" não só sugere um teor romântico entre os protagonistas, mas também representa parte do discurso contra a homofobia e o nacionalismo. Portanto, o conto matiza nosso entendimento da obra de Caio Fernando Abreu e da cultura e política durante a transição da ditadura à democracia. A biografia de Abreu, que morreu de aids em 1996 - na mesma década em que outras figuras públicas nacionais como Cazuza, Renato Russo, e Herbert "Betinho" José de Sousa -, teve um grande impacto na interpretação de sua obra. Mas além de sexualmente fluido com "um componente homossexual muito forte", ele também foi, como muitos artistas e escritores da época, altamente privilegiado por ter a oportunidade de refrescarse artisticamente e escapar dos anos de chumbo no exterior (Abreu, 2018a, p. 759). Durante o final do governo de Emílio Garrastazu Médici, de 1973 a 1974, o autor mudou-se da casa dos seus pais em Porto Alegre para a Europa, onde conheceu Estocolmo, Londres, Bélgica, Holanda

${ }^{4}$ Para consultar alguns exemplos, ver Ginzburg (2012), Benatti (2013) e Gonella (2015). 
e Paris, além de partes escondidas de si mesmo. ${ }^{5}$ Em virtude da sua contribuição à visão cosmopolita de Caio Fernando Abreu, que engloba sua crítica da homofobia, vale a pena reler "Aqueles dois" como artefato da transição da ditadura à democracia no Brasil.

"Aqueles dois" trata da história de dois homens, Raul e Saul, que moram num centro urbano não especificado e trabalham numa firma também anônima. $\mathrm{O}$ anonimato do cenário da história sugere a universalidade do conto. Poderia representar ora São Paulo, Rio de Janeiro ou Porto Alegre - cidades onde o autor trabalhou para várias revistas e editoras antes de escrever Morangos mofados -, ora qualquer outra metrópole do Brasil. São jovens, solteiros e "bonitos", segundo a opinião de todos na repartição (Abreu, 2018b, p. 406). Como todas as amizades na empresa, a amizade de Saul e Raul é inicialmente superficial, mas eles começam a passar tempo juntos, quando descobrem que têm muito em comum, além da coincidência de seus nomes. O narrador relembra que, quando eles se conheceram na firma, "Não chegaram a usar palavras como especial, diferente ou qualquer outra assim. Apesar de, sem efusões, terem se reconhecido no primeiro segundo do primeiro minuto" (Abreu, 2018b, p. 405). Encontrando solidariedade em sua mutualmente percebida (mas não especificada) "diferença", os dois acabam saindo muito para tomar café, assistir a filmes em casa, ir a festas juntos, tocar música e fofocar sobre seus colegas de trabalho. Enquanto sua amizade torna-se cada vez mais íntima, porém, seus colegas de trabalho começam a suspeitar algo fora do normal entre "aqueles" dois - pronome que demarca sua diferença. No fim da trama, Raul e Saul são despedidos por causa de cartas anônimas enviadas ao chefe:

Suarento, o chefe foi direto ao assunto: tinha recebido algumas cartas anônimas. Recusou-se a mostrá-las. Pálidos, os dois ouviram expressões como "relação anormal e ostensiva", "desavergonhada aberração", "comportamento doentio", "psicologia deformada", sempre assinadas por Um Atento Guardião da Moral. Saul baixou os olhos desmaiados, mas Raul levantou de um salto. Parecia muito alto quando, com uma das mãos apoiadas no ombro do amigo e a outra erguendo-se atrevida no ar, conseguiu ainda dizer a palavra nunca, antes que $o$ chefe, depois de coisas como a-reputação-de-nossa-firma ou tenho-que-zelar-pela-moral-dosmeus-funcionários, declarasse frio: os senhores estão despedidos (Abreu, 2018b, p. 411).

Como a passagem mostra, Raul registra a indignação da situação no seu corpo ao levantarse. Até contesta as acusações quando diz a palavra "nunca", mas os protagonistas carecem de poder para resistir à decisão do chefe. Depois de sair, eles param em frente ao prédio por uns minutos e observam que é "parecido com uma clínica psiquiátrica ou uma penitenciária" (Abreu, 2018b, p. 411). Aqui a demissão começa a transformar-se em uma benção com a (literal) mudança de perspectiva dos personagens. Além disso, o conto refere-se à altura dos protagonistas para ilustrar sua dignidade apesar de sua humilhação: "vistos de cima pelos colegas todos nas janelas, a camisa branca de um e a azul do outro, estavam ainda mais altos e mais altivos" (Abreu, 2018b, p. 411). No final, são seus companheiros de trabalho, e não os despedidos, que têm um final trágico por ficarem na empresa: "tinham a nítida sensação de que seriam infelizes para sempre. E foram" (Abreu, 2018b, p. 411). A ironia dessas frases finais do conto parece vingar a injustiça da demissão dos amigos.

Justiça poética de lado, no entanto, "Aqueles dois" retrata a sociedade brasileira durante a transição da Ditadura Militar. Embora o conto não especifique onde, nem em que ano, a história se passa perto do final da Ditadura Militar brasileira, que oficialmente durou desde o Golpe de Estado no Brasil em 1964 até a eleição presidencial de Tancredo Neves em 1985 (Green e Quinalha, 2014, p. 11). Diante das condições sociais representadas no conto como evidência, o enredo situa-se aproximadamente no período de publicação. Após ganhar a hostilidade de seus colegas de trabalho, apenas por passarem muito tempo juntos dentro e fora do trabalho, os protagonistas não são presos, torturados ou executados por insubordinação dos valores da nação, como as centenas de pessoas que foram desaparecidas durante os 21 anos de Ditadura Militar.

\footnotetext{
${ }^{5}$ Foi durante sua viagem à Europa que Abreu escreveu em uma carta: "tenho um componente homossexual muito forte. Até hoje, minhas relações heterossexuais sempre foram, sei lá, meio idiotas - porque, realmente, [...] o corpo feminino é uma coisa que não consegue me entusiasmar. Nunca fui exclusivamente homossexual ou exclusivamente heterossexual - creio que nunca serei” (Abreu, 2018a, p. 759).
} 
Contudo, eles também não se beneficiam de proteções legais, enquanto a empresa tem toda impunidade para discriminação. Raul e Saul gradualmente recebem o escrutínio de seus companheiros, até receberem a notícia de sua demissão devido a rumores de seu comportamento "imoral". Esses acontecimentos sugerem que o conto decorre no final da ditadura, não durante os anos de chumbo. Apesar de "certa abertura nos meios culturais e intelectuais para uma visão mais tolerante à homossexualidade" durante o período entre 1964 e 1967, a ditadura percebeu a homossexualidade (da mesma forma que o comunismo, o liberalismo e o ateísmo) como uma ameaça subversiva ao regime autoritário (Green e Quinalha, 2014, p. 19). Como resultado da associação entre as práticas homossexuais e a subversão política, a repressão, a censura e a violência contra as pessoas LGBT aumentaram depois de 1968. O texto não sugere que a história aconteça durante esse período da ditadura, mas depois do final do governo de Médici, em 1974, quando, por fim, houve novamente uma abertura gradual e lenta, dando espaço a grupos de oposição à ditadura, inclusive grupos de gays e lésbicas. A abertura, todavia, não terminou com a discriminação e o preconceito. A demissão de Saul e Raul comprova não somente a emergência do tema homossexual na literatura brasileira, mas também a crítica à repressão da homossexualidade no Brasil. O Estado não é ativamente violento no conto, mas também não protege os direitos civis dos personagens contra a discriminação. O chefe justifica a despedida de Raul e Saul apenas pela suspeita de eles terem um relacionamento romântico, sem provas e sem dar aos dois a oportunidade de se defenderem.

Esse aspecto do conto, de denunciar o tratamento aos homens gays durante a transição da ditadura, forma parte do que Eurídice Figueiredo (2017) chama de "teor testemunhal" da literatura. ${ }^{6}$ Para Figueiredo, a literatura cumpre um papel social que nem o jornalismo ou história atinge: "Ao criar personagens, ao simular situações, o escritor é capaz de levar o leitor a imaginar aquilo que foi efetivamente vivido por homens e mulheres" (2017, p. 29). Além disso, como a literatura depende da imaginação para indagar as emoções dos personagens, Figueiredo defende que a literatura é um arquivo da história superior até à própria história:

A despeito do enorme trabalho realizado por historiadores e jornalistas, só a literatura é capaz de recriar o ambiente de terror vivido por personagens afetados diretamente pela arbitrariedade, pela tortura, pela humilhação, pois como afirma Jacques Rancière (2009, p. 58): "o real precisa ser ficcionado para ser pensado". Numerosos críticos e pensadores têm salientado tanto a necessidade quanto as possibilidades da ficção em recriar, através da imaginação e da liberdade composicional, não aquilo que realmente aconteceu, o que é impossível, como já apontava Walter Benjamin no seu seminal texto sobre os conceitos da História, mas algo que possa evocar o que pensaram, sentiram ou sofreram os personagens (Figueiredo, 2017, p. 43).

Em "Aqueles dois", os protagonistas lamentam a discriminação que sofrem somente no momento em que são despedidos. "Meses depois", porém, parecem agradecer terem sido dispensados de uma empresa cheia de pessoas tão insípidas, vazias e homogêneas (Abreu, 2018b, p. 405). Dessa forma, a empresa simboliza a nação na época da ditadura, em que muitos artistas e intelectuais foram expulsos (ou se exilaram), enquanto o conto representa os protagonistas como cosmopolitas, cultos e sofisticados demais para um lugar tão mesquinho. Em vez da narrativa de repressão, tortura e violência do período inicial da ditadura, "Aqueles dois" mostra o irônico alívio dos protagonistas de serem excluídos da empresa onde se sentiam presos. Para liberar-se do cenário desolador, Raul e Saul buscam refúgios nas artes que apreciam. Ao introduzir elementos intertextuais através dos gostos cosmopolitas deles, por meio da literatura, o conto torna a comunidade imaginária da nação brasileira mais cosmopolita.

\footnotetext{
${ }^{6}$ Embora seja ficção, "Aqueles dois" demonstra o "teor testemunhal" da literatura por tratar-se do preconceito da sociedade à homoafetividade. O conto, portanto, encaixa na análise de Figueiredo da literatura como arquivo da ditadura brasileira: "Tratar da literatura sobre a ditadura convoca categorias de pensamento como o testemunho, o trauma, o exílio, a memória, o arquivo, enfim, a responsabilidade dos autores frente à História e aos leitores. Se toda literatura tem um 'teor testemunhal' [...] não há dúvida de que a literatura que tematiza os grandes desastres do século XX tem um forte caráter de testemunho. As narrativas brasileiras se distanciam em suas estratégias narrativas tanto do gênero testimonio hispano-americano, em geral atravessado por um mediador, quanto do testemunho da Shoá, fortemente marcado pela psicanálise” (Figueiredo, 2017, p. 41).
} 


\section{Sexualidade e intertextualidade: arte, espaço interior e segurança no conto}

Em seu livro Intertextuality (2011), Graham Allen se nutre do pós-estruturalismo para avançar em seu argumento de que os textos, infelizmente para nós, não têm nenhum significado "verdadeiro" que espera, dormente, para ser descoberto, despertado e revelado ao público. Longe disso, um texto pode criar diversos significados, não somente em si mesmo, mas em relação com outros textos. Por isso, Allen nos instrui que é preciso investigar essas relações intertextuais para explorar as possibilidades do que um texto pode "significar". Ele diz que "Interpretar um texto, descobrir seu significado, ou significados, é rastrear essas relações" (Allen, 2011, p. 1, tradução nossa). Então, se os "intertextos" podem mudar o significado de uma obra literária, deveríamos atender à epígrafe, que vem do poema "So long!" do poeta estadunidense Walt Whitman. Além disso, Allen mostra que a intertextualidade pode referir-se não só à literatura mas também às artes visuais (2011, p. 174). Sendo assim, este trabalho analisa "Quarto em Arles", do pintor holandês Vincent Van Gogh, que aparece e reaparece no conto dentro dos quartos dos protagonistas. Como a intertextualidade forma parte da criação do significado dos textos, vale a pena explorar suas possíveis funções em "Aqueles dois". A dualidade entre Van Gogh e Whitman nos ajuda a observar outras dualidades no conto: entre os espaços interiores e exteriores, os dormitórios e o escritório e a segurança e a liberdade, neste caso, de viver autenticamente em público.

Ao longo do desenvolvimento da amizade de Raul e Saul, os dormitórios deles representam, cada vez mais, um refúgio para escapar da cultura da firma onde trabalhavam, caracterizada dentro do conto como superficial e vazia ou, nas palavras deles, "um deserto de almas" (Abreu, 2018b, p. 405). Dentro dessa cultura empresarial, Saul e Raul não apenas se consideram excluídos, mas também superiores. Começam a passar tempo juntos depois de descobrir que compartilham o mesmo gosto pelo cinema. Embora Saul diga que gosta de Infâmia, com Audrey Hepburn e Shirley MacLaine, um filme "antigo" que "ninguém conhece", Raul responde que não só o conhece, como o adora. Os interesses de Saul e Raul, ostensivamente mais refinados (e curiosamente mais cosmopolitas) do que os gostos do resto dos funcionários, parecem servir como ponto de partida para a amizade de "Aqueles dois". Eles se reúnem cada vez mais em casa para assistir a filmes de Hollywood, cantar e ouvir boleros em espanhol e admirar quadros. Além de um refúgio da cultura tediosa da repartição em que trabalhavam, os quartos de Saul e Raul servem como um espaço fora do olhar da sociedade, no qual não têm de se conformar com as normas de relacionamento entre dois homens da cultura dominante no Brasil daquela época. Quando se conhecem, os dois homens são sozinhos: Raul teve um casamento fracassado e Saul teve um noivado desfeito. Logo, depois de uma festa, Saul e Raul "concordam, bêbados, que estavam ambos cansados de todas as mulheres do mundo, suas tramas complicadas, suas exigências mesquinhas. Que gostavam de estar assim, agora, sós, donos de suas próprias vidas" (Abreu, 2018b, p. 408). O interesse das mulheres que olham para eles, e que "ficaram nervosas quando eles surgiram, tão altos e altivos", não é correspondido (Abreu, 2018b, p. 406).

A partir do momento em que se conhecem, Raul e Saul se preocupam muito um com o outro. Entre o início da primavera e o do verão, intervalo de tempo entre o aniversário de um e outro, a mãe de Raul falece. Ele, então, passa uma semana fora e, como resultado, "desorientado, Saul vagava pelos corredores da firma esperando um telefonema que não vinha" (Abreu, 2018b, p. 409). Além de andar distraído no seu trabalho, Saul "bebeu bastante", e também sonha com Raul uma noite. Quando Raul finalmente volta, telefona para a repartição "pedindo a Saul que fosse vê-lo" (Abreu, 2018b, p. 410). Quando eles se vêm em casa, Raul está mudado, com barba e um rosto mais sério. Quando Saul estava a ponto de sair da casa de Raul, Raul começa a chorar. A partir do luto inesperado de Raul, a cena seguinte ocorre: "Sem saber ao certo o que fazia, Saul estendeu a mão e, quando percebeu, seus dedos tinham tocado a barba crescida de Raul", e "abraçaram-se fortemente. E tão próximos que um podia sentir o cheiro do outro [...]. Durou muito tempo. A mão de Saul tocava a barba de Raul, que passava os dedos pelos caracóis miúdos do cabelo do outro. Não diziam nada" (Abreu, 2018b, p. 410). 
Depois de seu abraço dramático e íntimo, falam sobre sua amizade usando "palavras grandes" como "ninguém, mundo" e "sempre" (Abreu, 2018b, p. 410). Também se apertam "as duas mãos ao mesmo tempo, olhando-se nos olhos" (Abreu, 2018b, p. 410), mas só dentro da privacidade da casa de Raul.

A cena do abraço representa um passo importante na abertura da amizade de Raul e Saul, mas vemos mais um episódio de intimidade que acontece à porta fechada, "na noite de trinta e um", antes do Ano-novo (Abreu, 2018b, p. 410). Os protagonistas celebram na quitinete de Raul e bebem "até quase cair". Nessa noite, "na hora de deitar, trocando a roupa no banheiro, muito bêbado, Saul falou que ia dormir nu. Raul olhou para ele e disse você tem um corpo bonito. Você também, disse Saul, e baixou os olhos. Deitaram ambos nus, um na cama atrás do guarda-roupa, outro no sofá" (Abreu, 2018b, p. 411). Como na cena do abraço, voltamos a ver o símbolo do cigarro quando o narrador descreve que, "Quase a noite inteira, um conseguia ver a brasa acesa do cigarro do outro, furando o escuro feito um demônio de olhos incendiados" (Abreu, 2018b, p. 412). Então, outra vez, o elemento homoerótico é mais ambíguo e abstrato que concreto. Não fazem amor e nem sequer se beijam - só passam a noite fumando. Mesmo assim, sua nudez, seus olhares e seus comentários representam uma intimidade entre homens que só seria possível em privado. No espaço interior da quitinete, Raul e Saul sentem-se seguros para expressar sua amizade de uma maneira que seria condenada como "fora do normal" em público.

A relação entre a segurança e os espaços interiores do conto, sobretudo os quartos de Saul e Raul, é reforçada por meio de uma alusão dentro do texto ao quadro "Quarto em Arles" (1889), de Vincent Van Gogh. No segundo capítulo do conto, o narrador descreve os protagonistas como solitários na cidade onde moram e trabalham, e que "diria também que não tinham nada, mas não seria inteiramente verdadeiro" - ou seja, antes de se conhecerem, não têm amigos, mas têm posses materiais (Abreu, 2018b, p. 406). Entre os bens pessoais de Saul estão "um livro com reproduções de Van Gogh" e "na parede do quarto de pensão, outra reprodução de Van Gogh: aquele quarto com a cadeira de palhinha parecendo torta, a cama estreita, as tábuas do assoalho, colocado na parede em frente à cama" (Abreu, 2018b, p. 406)..$^{7}$ No entanto, a importância do quadro no contexto do conto é deixada para ser construída pelo próprio leitor. Como o narrador do conto sugere, o quadro não representa um quarto elegante, mas simples, pequeno e acolhedor, como os quartos de Saul e Raul. Na breve descrição do quadro, o quarto em Arles, representado no estilo pós-impressionista do artista, há uma cama com dois travesseiros, além duas cadeiras, possivelmente para receber companhia.

Um comentário do próprio artista sobre sua intenção pode ajudar a iluminar a função do quadro dentro do conto. Van Gogh disse que queria que o quadro transmitisse uma sensação de descanso. Escreveu numa carta que, por sua simplicidade, "Quarto em Arles "deve sugerir uma tranquilidade e descanso absoluto ao espectador. Em resumo, a mera vista do quadro deve ser repousante ao espírito, ou melhor ainda, à imaginação" (R. M. F., p. 93-94, tradução nossa). No conto, por outro lado, o narrador ecoa a sensação de tranquilidade e imaginação do artista ao descrever Saul em seu quarto: “Deitado, Saul tinha às vezes a impressão de que o quadro era um espelho refletindo, quase fotograficamente, o próprio quarto, ausente apenas ele mesmo. Quase sempre, era nessas ocasiões que desenhava" (Abreu, 2018b, p. 406). Nesse momento, o quadro representa a segurança e o conforto do quarto pequeno de Saul - conforto de que homens que amam a outros homens ainda eram privados no Brasil nos últimos anos da ditadura. A propósito disso, Pereira $(2016$, p. 89) sugere que "Quarto em Arles" não é a única referência à arte no conto. Embora não mencione Van Gogh, comenta que, "no conto ainda é possível ver famosas obras de arte, como 'Nascimento de Vênus', de Botticelli, fazendo uma possível referência à pureza, à beleza, e, possivelmente, à paixão". Como a imagem da deusa do amor na mitologia romana, a referência ao quarto íntimo de Van Gogh reforça a temática homoafetiva em "Aqueles dois".

Além de sugerir o tema homossexual, no entanto, o quadro reforça novamente o quarto como símbolo de segurança e intimidade domiciliar, no momento em que Raul visita Saul em

\footnotetext{
${ }^{7}$ Para ver uma imagem e conhecer uma análise mais aprofundada de “Quarto em Arles”, ver Lewandowski (2016).
} 
sua casa pela primeira vez: "Raul viu os desenhos, olhando longamente a reprodução de Van Gogh, depois perguntou como Saul conseguia viver naquele quartinho tão pequeno. Parecia sinceramente preocupado. Não é triste? perguntou. Saul sorriu forte: a gente acostuma" (Abreu, 2018b, p. 408). Embora Raul se preocupe pelo tamanho abarrotado do quarto de Saul, Saul responde com calma, como se entendesse que seu dormitório representa um espaço de repouso tanto quanto o dormitório de Van Gogh em Arles. Por isso, quando Saul oferece a Raul o quadro de "Quarto em Arles" para seu aniversário, pode-se interpretar o presente como um ato de compartilhar a sensação de tranquilidade que ele sente em casa. Afinal, essa sensação de segurança é o que permite que os protagonistas expressem seus desejos de intimidade fora do olhar crítico da sociedade, e dentro da proteção de quatro paredes - talvez azuis como as do quarto em Arles - que lhes davam uma sensação de tranquilidade, como se estivessem totalmente em casa no Brasil da época da transição da Ditadura Militar.

\section{O desejo de estar "fora": referências à poesia, à música e ao cinema estrangeiros}

Enquanto a presença de "Quarto em Arles" reforça o sentido de segurança que os protagonistas sentem dentro do apartamento de cada um, a epígrafe do conto sugere seu desejo de liberdade fora da casa, ou seja, fora do armário no Brasil. Esse desejo não se expressa de forma explícita em "Aqueles dois", mas por meio de referências intertextuais à poesia, à música e ao cinema (além de arte) estrangeiros. Dito dessa forma, por um lado, estar "fora" refere-se à impossibilidade ainda de estar fora do armário no Brasil e, por outro, à busca por expressões de homoafetividade nas culturas estrangeiras. Antes de tudo, a epígrafe, dedicada a Rofran Fernandes, é uma passagem do poema "So long!" (1900) de Walt Whitman, cujos versos são:

I announce adhesiveness,

I say it shall be limitless, unloosen'd.

I say you shall yet find the

friend you were looking for (Abreu, 2018b, p. 405).

Como era a relação entre Caio Fernando Abreu e Rofran Fernandes, que também atuava no mundo das artes como ator de teatro, dramaturgo e crítico? O autor quis sugerir que o conto representa uma alegoria do relacionamento deles, ou anunciar a "adesividade" entre eles, livre e sem limites? A epígrafe parece convidar especulações sobre quem era Rofran Fernandes para Caio Fernando Abreu, amigo, amante ou talvez ídolo literário. A escolha da passagem de Walt Whitman como epígrafe é provocativa e sugestiva, pois os temas de desejo homoafetivo na sua poesia levaram vários estudiosos e leitores a especular que o poeta era homossexual. Deixando a biografia disputada de Whitman à parte, Carolina Castellanos Gonella faz uma conexão entre os elementos homoeróticos da obra de Whitman com o conto. Ela diz: "Considerando que os críticos estudaram o elemento homoerótico de Leaves of grass [...], a citação de Whitman no conto não apenas estabelece a ideia de amizade harmônica do começo, mas também ajuda a apresentar a dimensão homoerótica no texto" $(2015$, p. 5).

Estendendo a análise de Gonella (2015), observa-se que "So long!" contribui para o cosmopolitismo do texto e ressoa com a falta de liberdade de expressão homoafetiva no Brasil da transição. Mesmo que fosse a intenção de Whitman, ou não, seu poema captura o desejo de estar "fora do armário" em público. Além disso, é significativo que a epígrafe seja em inglês, de um poeta canônico estadunidense e reconhecido pela temática homoerótica de seus poemas. Isso representa uma introdução apropriada à visão cosmopolita do autor, que o conto reforça com referências internas também aos boleros da América hispânica e ao cinema de Hollywood. Além de parodiar a monotonia e o monoculturalismo do Brasil da época, o conto constrói sua própria visão de um Brasil multicultural, compartilhado entre os protagonistas, que sutilmente sugere a tensão homoerótica. Por causa da diferença de "Aqueles dois", a sociedade não aprova a amizade cada vez mais íntima deles. No princípio do conto, o narrador descreve a atração das mulheres da empresa pelos protagonistas, mas, quando os dois já são inseparáveis, diz que, "as moças em volta espiavam, às vezes cochichavam sem que eles percebessem" (Abreu, 2018b, p. 
408). Os homens da repartição também expressam sua desaprovação segundo a descrição do narrador: "Os funcionários barrigudos e desalentados trocaram alguns olhares que os dois não saberiam compreender, se percebessem. Mas nada perceberam, nem os olhares nem duas ou três piadas. Quando faltavam dez minutos para as seis, saíram juntos, altos e altivos, para assistir ao último filme de Jane Fonda" (Abreu, 2018b, p. 409). Finalmente, quando são demitidos, alguém grita para eles "Ai-ai!" de uma janela, mas eles também não percebem (Abreu, 2018b, p. 411). Dessa forma, ao mesmo tempo que o conto comprova a falta de liberdade que Saul e Raul sentem em espaços públicos, parece que eles vivem em seu próprio mundo, construído pela arte, literatura e cinema que tanto apreciam.

Os versos de "So long!" ecoam o desejo dos protagonistas de se relacionar à sua própria maneira, sem julgamentos. A epígrafe do conto trata de uma promessa de encontrar "o amigo que você estava buscando", mas, segundo Ed Folsom (2008), o poema também representa o anseio de cumprir a mesma promessa. Folsom escreve que a expressão em inglês "'so long'" não só significa "adeus", "mas também ressoa com o adiamento do desejo" (2008, p. 130). Essa interpretação de "So long!" faz eco com o sonho de Saul quando a mãe de Raul morre. No sonho, Saul "caminhava entre as pessoas da repartição, todas de preto, acusadoras. À exceção de Raul, todo de branco, abrindo os braços para ele. Abraçados fortemente, e tão próximos que um podia sentir o cheiro do outro" (Abreu, 2018b, p. 410). Aqui, o sonho de Saul expressa seu desejo de intimidade física e sentimental com Raul, mas também representa o anseio de amá-lo apesar da sociedade - as pessoas "acusadoras" que olham para eles com desprezo. Como o poema, o conto representa um contraste entre o sonho e a realidade, entre a promessa e o anseio. Por isso, a interpretação de Folsom de "So long!" pode ser aplicada à problemática homossexual no Brasil dos anos 1980. Como o poema, "Aqueles dois" também representa o sonho de liberdade ou, também, infelizmente, "o diferimento de um sonho, ou se o sonho é com um amigo ou ser querido ou a realização de um sonho nacional de liberdade e igualdade" (Folsom, 2008, p. 130). Mas, além do sonho dos protagonistas de se amar em público, como interpretamos a escolha de introduzir o conto com um trecho de "So long!", um poema em inglês por Walt Whitman, que é considerado um dos fundadores da poesia estadunidense?

Como só uma das referências intertextuais às artes do exterior, a epígrafe expressa certo desprezo pela "aparente repressão e mediocridade" da cultura brasileira durante a época da Ditadura Militar, e a preferência das classes intelectuais pela cultura estrangeira. É possível que o conto contribua para o estereótipo da inferioridade brasileira, conhecida como o "complexo de vira-lata", termo cunhado pelo dramaturgo Nelson Rodrigues. Contudo, as diversas referências não só à arte e à poesia, mas também à música e ao cinema estrangeiros, formam parte do discurso do conto contra a ditadura. A visão cosmopolita e internacional (com preferência por Europa e Estados Unidos) não se encaixa no discurso de nacionalismo da ditadura brasileira, e expressa um desejo por um Brasil mais aberto ao multiculturalismo, inclusive à homoafetividade, e a certo intelectualismo multicultural além das fronteiras da pátria. Os protagonistas desprezam o futebol, o passatempo preferido dos seus colegas de trabalho, e preferem os filmes de Hollywood e os boleros hispano-americanos, além dos quadros de Vincent Van Gogh. A primeira aparência do bolero acontece quando Raul "pegou o violão e cantou 'Tu [sic] me acostumbraste" para Saul uma noite (Abreu, 2018b, p. 408). Como podemos ver nesse trecho da letra, o tema é romântico: "sutil llegaste a mí como una tentación llenando de inquietud mi corazón" (Abreu, 2018b, p. 408). Segundo a interpretação de Lizandro Carlos Calegari (2007, p. 130), "o conteúdo das músicas sugerido pelos trechos cantados por Saul e pelo título delas assinala que há um grau de afeto entre os dois. É isso, talvez, o que o narrador pretenda enfatizar". Pereira concorda que, "as canções, como 'Tu me acostumbraste', 'Contigo en la distancia' e 'Noche de ronda', além de 'Nossas vidas', cantada por Dalva de Oliveira, têm claramente certo tom piegas, com expressão de saudade, tristeza e melancolia, além de profundo teor romântico" (2016, p. 89).

Complementado os comentários de Calegari (2007) e Pereira (2016), além de reforçar o teor romântico do conto, pontuamos que a inclusão de música hispano-americana expande os horizontes das próprias letras brasileiras como uma literatura e cultura cosmopolita, aberta e 
internacional. Além dos boleros, Pereira (2016) argumenta que os filmes referenciados no conto também reforçam o tema do homoerotismo: "Junto com [as músicas], o conto apresenta ao seu leitor alguns filmes que se ligam intimamente com os personagens centrais: 'Infâmia' (The children's hour), de 1961, de William Wyler, adaptado da peça de Lilian Hellman, conta a história de duas professoras que são acusadas por uma aluna de terem um relacionamento homoafetivo" (Pereira, 2016, p. 89). Infâmia, sem coincidência, é o primeiro filme que os protagonistas assistem juntos, além de ser um dos filmes favoritos deles. Como Pereira indica (2016), o filme trata do escândalo em torno de um relacionamento lésbico entre as duas protagonistas, Karen e Martha, interpretadas por Audrey Hepburn e Shirley MacLaine, respectivamente. Buscando um pretexto para não ter de voltar à escola, Mary Tilford, uma aluna da escola particular gerenciada por Martha e Karen acusa as duas de estarem em um relacionamento "não natural". Apesar de ser mentira, Martha confessa que a menina, de fato, estava certa ao perceber que ela sempre amou Karen. As vidas das professoras desandam ao longo do filme, até o suicídio trágico de Martha.

Levando-se em conta o enredo de Infâmia, o final de "Aqueles dois" revisa o destino dos personagens do filme. Após sua demissão da firma, eles abraçam o desconhecido, enquanto seus velhos colegas de trabalho são condenados à infelicidade eterna. Em outras palavras, o conto inverte o destino de Infâmia, em que a sociedade sofre uma tragédia e os protagonistas desfrutam de um "final feliz de Hollywood". Dessa forma, Infâmia representa escapismo em dois sentidos dentro do conto: é uma oportunidade de os protagonistas se verem representados no cinema por personagens queer, escapar da realidade repressiva da vida e do trabalho. Por meio do filme, em conjunto com "So long!", de Walt Whitman, e os boleros, a intertextualidade do conto expressa o desejo de estar "out" do Brasil, um país que se tornava mais cosmopolita com a publicação de Morangos mofados. É importante notar aqui que os Estados Unidos apoiaram o golpe militar em 1964. No entanto, as referências à cultura estrangeira fazem parte da crítica da sociedade brasileira durante a Ditadura Militar. Desse jeito, a intertextualidade no conto atua como um espelho para a sociedade brasileira e para o público leitor também. Ao mesmo tempo que os protagonistas se refugiam na arte, poesia, música e cinema de outros países, "Aqueles dois" convida os próprios leitores a escaparem no mundo do próprio conto.

\section{A importância das artes: lendo Caio Fernando Abreu depois da ditadura}

Por meio das referências intertextuais em "Aqueles dois", a obra de Caio Fernando Abreu continua sendo relevante em nossos tempos para nos provocar a refletir sobre impacto da arte em nossas vidas. No final do conto, a cena sombria da despedida dos protagonistas adquire um toque de inesperada ternura, graças à letra do bolero favorito de Raul, escrita à mão por ele como presente a Saul: "Raul guardou no grande envelope pardo um par de enormes olhos sem íris nem pupilas, presente de Saul, que guardou no seu grande envelope pardo a letra de 'Tu me acostumbraste', escrita por Raul numa tarde qualquer de agosto e com algumas manchas de café" (Abreu, 2018b, p. 411). Nessa passagem magistral, o conto nos mostra que, mesmo nos momentos mais escuros, a arte continua lembrando aos protagonistas do grande afeto entre eles. Além do que se encontra em "Aqueles dois", Caio Fernando Abreu incluía várias citações - em seus contos, romances e peças de teatros -, como epígrafes ou referências intertextuais. A eminente presença da intertextualidade na obra do autor demonstra a profunda cultura dele e seu próprio amor pelas palavras. E essas caraterísticas, além do seu afeto pelos homens, marcam tanto o autor quanto seus personagens Raul e Saul como "diferentes" durante a Ditadura Militar no Brasil. Desse modo, o estudo da intertextualidade na obra de Caio Fernando Abreu abre caminhos em nosso entendimento não só de "Aqueles dois", mas também da complicada transição da ditadura brasileira.

A intertextualidade reforça a crítica à discriminação contra os homossexuais no Brasil nessa mesma época. Já em sua quarta edição, o livro Devassos no paraíso: a homossexualidade no Brasil, da colônia à atualidade, de João Silveiro Trevisan (2018), mostra como escritores como Caio Fernando Abreu publicavam conteúdo homoerótico durante a ditadura. Trevisan explica que, "A partir de meados da década de 1970, o amor homossexual começou a furar a barreira da censura ditatorial e 
dos setores mais reacionários, para chegar até as capas de revistas de circulação nacional - caso da IstoÉ, que dois anos antes da Time apresentou em sua capa duas mãos masculinas ternamente enlaçadas, ilustrando matéria sobre o tema" (Trevisan, 2018, p. 279).

Eurídice Figueiredo (2017) afirma que a temática homoerótica (re)emergiu na literatura brasileira durante esse período de abertura. Em A literatura como arquivo da ditadura brasileira, Figueiredo divide a literatura da ditadura em três períodos: de 1964 a 1979; 1979 a 2000; e 2000 a 2016, sendo que os últimos períodos têm um olhar principalmente retrospectivo para compensar as vozes caladas entre o golpe e a Lei da Anistia. Depois da rígida censura do primeiro período, "O segundo período se caracteriza por relatos autobiográficos de ex-presos políticos exiliados, beneficiados pela lei da anistia, que voltaram ao Brasil, como Fernando Gabeira, ou recém-saídos da prisão ou da clandestinidade" (Figueiredo, 2017, p. 48). De volta ao Brasil, após lutar contra a Ditadura Militar como membro da Vanguarda Popular Revolucionária e passar nove anos no exílio, Gabeira publicou o livro autobiográfico O que é isso companheiro? em 1979, mesmo ano da promulgação da Lei de Anistia. Figueiredo descreve-o como "um dos poucos livros de testemunho de ex-militantes a abordar a questão da sexualidade, o que explica o título um pouco jocoso [...]. Apesar de revolucionários, os militantes eram preconceituosos em relação à homossexualidade" (Figueiredo, 2017, p. 66). Entre outras coisas, o livro trata do guerrilheiro Herbert Daniel, que "foi vítima desse preconceito por ser homossexual" (Figueiredo, 2017, p. 66). Embora Figueiredo enfoque principalmente relatos autobiográficos e romances sobre exílio e retorno durante esse segundo período da literatura de ditadura brasileira, "Aqueles dois" ilustra o teor testemunhal da ficção e a persistência da homofobia, mesmo depois dos duros anos de chumbo.

Além das repressões sofridas por homens suspeitos de amar outros homens, o conto serve para comprovar a complexa política de censura durante o segundo período da literatura da ditadura, no qual a tolerância ao homossexual ainda era tênue. Por exemplo, Trevisan nota um forte ressurgimento de intolerância moralista, oficializada pelo Estado, coincidentemente (ou não) em 1982, ano da publicação de Morangos mofados. Como "as elites brasileiras sempre se apresentaram muito defensivas e, por isso mesmo, vulneráveis ao fantasma do desejo desviante" (Trevisan, 2018, p. 155), Trevisan argumenta que as práticas homossexuais foram um alvo de repressão ao longo da história brasileira, inclusive nos últimos anos da Ditadura Militar:

Os grupos oligárquicos estiveram envolvidos em atividades que coibiram incansavelmente as práticas homossexuais entre os brasileiros em vários momentos - como a Inquisição, os códigos penais, as portarias policiais e a censura estatal. Para tanto, utilizaram-se até mesmo de distorções na história do país, recontada de acordo com ditames moralizantes e preconceituosos. Assim, em 1982, o então ministro da Educação e Cultura, general Rubem Ludwig, fazia coro com o presidente João Figueiredo na articulação de uma campanha contra a escalada pornográfica porque, segundo ele, o erotismo não tinha raízes na tradição cultural brasileira (Trevisan, 2018, p. 155-156).

Como consequência dessa campanha contra a pornografia, Trevisan nota que, no olhar do órgão oficialmente encarregado da responsabilidade de censura, "foram visados em especial os personagens e situações homossexuais que o boom da permissividade inseriria em programas de televisão - pois, como reclamava um membro do Conselho Superior de Censura: 'O que dá de viado na televisão não é de brincadeira" (Trevisan, 2018. p. 156). Finalmente, Trevisan aponta que mesmo o presidente do Conselho Superior de Censura concordava com a campanha contra representações de homossexualidade na esfera cultural: "Por sua vez, o presidente do Conselho Superior de Censura, na época, afirmava que 'o público brasileiro, fora de Ipanema, conserva muitos de nossos valores tradicionais da moral e dos bons costumes'. E completava, convicto: 'O homossexualismo e o amor livre não entraram na mente dessa gente'" (Trevisan, 2018. p. 156). É precisamente nesse ambiente de censura de afetividade homossexual dos anos 1980 que Caio Fernando Abreu publicou "Aqueles dois".

Infelizmente, essa crítica social ainda tem relevância após a ditadura, pois, mesmo depois de 1985, o perfil LGBT do Brasil continua sendo complicado. Ecoando a demissão de Raul e Saul em "Aqueles dois", Trevisan explica que, "Em 1993, o vereador Renildo dos Santos, do vilarejo de Coqueiro Seco, no Alagoas, confessou-se bissexual, num programa de rádio local. Depois 
disso, foi afastado da Câmara Municipal, por 'quebra de decoro'" (Trevisan, 2018, p. 156). Mais recentemente ainda, o assassinato de Marielle Franco, vereadora negra, que lutava pelos direitos das pessoas LGBT, e os inúmeros comentários de Jair Bolsonaro, "homofóbico de carteirinha", eleito presidente da República em 2018, são fatos conhecidos (Trevisan, 2018, p. 441). ${ }^{8}$ A decisão do Supremo Tribunal Federal de que homofobia é crime, em maio de 2019, representa um raio de esperança na história LGBT do país. Sobre essa decisão, só o tempo dirá se "Aqueles dois" continuará sendo uma alegoria do legado da ditadura em nosso século. Segundo a Folha de S. Paulo, o Grupo Gay da Bahia forneceu dados sobre 420 mortes violentas de LGBTs no Brasil registradas em 2018: 45\% foram de gays, 39\% trans, $12 \%$ lésbicas, 1,9\% bissexuais e até 1,2\% heterossexuais, ou seja, "pessoas que saíram em defesa de algum LGBT que estava sendo agredido ou que foram confundidas por um LGBT" (TODAS..., 2019). ${ }^{9}$ Sendo assim, o tema da homofobia continua sendo relevante no século XXI, até para pessoas que não se identificam como LGBT. Dada a ambiguidade do relacionamento de Raul e Saul, poder-se-ia dizer que "Aqueles dois" tem um teor não somente testemunhal, mas também profético. Ainda que os protagonistas encontrem a paz e a segurança em seus próprios quartos, a promessa de encontrar a justiça e a liberdade fora desses espaços ainda fica por cumprir, mesmo depois do fim oficial da Ditadura Militar, em 1985. Enquanto a sociedade brasileira ainda continua em transição, a obra de Caio Fernando Abreu nos lembra do poder das artes, não somente para denunciar seu legado no presente, mas também para nos inspirar a continuar imaginando um mundo mais humano, interconectado e afetivo para o futuro.

\section{Referências}

ABREU, Caio Fernando (2018a). Contos completos. São Paulo: Companhia das Letras.

ABREU, Caio Fernando (2018b). Aqueles dois. In: ABREU, Caio Fernando. Contos completos. São Paulo: Companhia das Letras. p. 405-411.

ALLEN, Graham (2011). Intertextuality. 2. ed. London: Routledge.

BENATTI, André Rezende (2013). “Um deserto de almas": a aversão ao sentimento humano no conto "Aqueles Dois", de Caio Fernando Abreu. Revista Literatura em Debate, Frederico Westphalen, v. 7, n. 12, p. 281-291. jan./jun. Disponível em: https:// bit.ly/3cNew90. Acesso em: 27 abr. 2016.

CALEGARI, Lizandro Carlos (2007). Literatura e homoerotismo: a perspectiva queer em Morangos mofados, de Caio Fernando Abreu. Luso-Brazilian Review, Madison, WI, v. 44, n. 2, p. 117-133. Disponível em: http://lbr.uwpress.org/content/44/2/117.abstract. Acesso em: 27 abr. 2016.

FIGUEIREDO, Eurídice (2017). A literatura como arquivo da ditadura brasileira. Rio de Janeiro: 7Letras.

FOLSOM, Ed (2008). So long, so long! Walt Whitman, Langston Hughes, and the art of longing. In: BLAKE, David Haven; ROBERTSON, Michael. Walt Whitman: where the future becomes present. Iowa City: University of Iowa Press.

GINZBURG, Jaime (2012). Crítica em tempos de violência. São Paulo: Editora da USP; Fapesp.

GONELLA, Carolina Castellanos (2015). Beautiful male bodies: gay and male homoerotic relationships in Caio Fernando Abreu's Morangos mofados. Chasqui, Tempe, Arizona, v. 44, n. 2, p. 272-284. Disponível em: https:// bit.ly/344EsZN. Acesso em: 27 abr. 2017.

GREEN, James Naylor; QUINALHA, Renan Honório (2014). Ditadura e homossexualidades: repressão, resistência e a busca da verdade. São Carlos, SP: EdUFSCar.

LEWANDOWSKI, Hervé (2016-2019). Vincent van Gogh (1853-1890): Van Gogh's bedroom in Arles. Paris: Musée d'Orsay. Disponível em: https:/ / bit.ly/2URj1at. Acesso em: 31 maio 2019.

\footnotetext{
${ }^{8}$ Para uma lista completa dos comentários do presidente eleito, veja Devassos no paraíso (Trevisan, 2018, p. 441-442).

${ }^{9}$ Para uma análise detalhada da criminalização da transhomofobia, ver Todas as Letras (2019).
} 
PEREIRA, Bruno Santos (2016). A construção do (des)sabor d'Aqueles dois Morangos mofados. Jangada, Viçosa, n. 7, p. 77-91. ago. Disponível em: https:/ / bit.ly/342dcLr. Acesso em: 30 maio 2019.

R. M. F. (1926). Van Gogh in Arles. Bulletin of the Art Institute of Chicago, v. 20, n. 7, p. 92-94.

TODAS as Letras (2019). Agora é crime, sim. Mas como e por quê? Episódio 2. [Locução de]: Renan Sukevicius. São Paulo: Folha de S. Paulo. Podcast. Disponível em: https://spoti.fi/3dOyIHW. Acesso em: 26 jun. 2019.

TREVISAN, João Silvério (2018). Devassos no paraíso: a homossexualidade no Brasil, da colônia à atualidade. 4. ed. Rio de Janeiro: Objetiva. 